\author{
Александар М. МИЛАНОВИЋ \\ Филолошки факултет \\ Универзитета у Београду
}

\title{
БИБЛИОГРАФИЈА РАДОВА О ЈЕЗИКУ \\ „ПРЕДВУКОВСКОГ ПЕРИОДА” КАО РЕСУРС ЗА ИСТОРИЈУ СРПСКОГ КЬИЖЕВНОГ ЈЕЗИКА
}

\begin{abstract}
У раду се описује историјат настанка библиографије радова о језику „предвуковског периода", а потом се анализирају теоријско-методолошке и практичне препреке у његовој изради. Скицирају се структура и техничка решења у будућој штампаној и електронској верзији библиографије, назначавају се правци и принципи њиховог исправљања, попуњавања и допуњавања и указује се на значај ових процеса у склопу истраживања из историје српског књижевног језика.
\end{abstract}

Кључне речи: библиографија, библиографска референца, славеносрпски језик, рускословенски језик, руски књижевни језик, доситејевски језик, орфелиновски језик, периодизација.

1. Научно интересовање за новији период развоја српског књижевног језика непосредно пре Вукове реформе, а који је условљен Великом сеобом под патријархом Арсенијем Чарнојевићем, расло је током читавог 20. века, а наставља се и у 21. веку. ${ }^{1}$ После пионирских радова Александра Белића и Милована Сучевића у Србији, као и Бориса Унбегауна у иностранству, порасту лингвистичких сазнања о различитим типовима језика српске писмености и тадашњој језичкој ситуацији својим монографијама, студијама и научним контактима првенствено је допринео Александар Младеновић током друге половине 20. века, али и читав тим стручњака који се под његовим директним руководством и под будним оком Павла Ивића формирао у Новом Саду.

\footnotetext{
*aleksandar.jus@gmail.com

${ }^{1}$ Врло илустративан може бити податак да су на јубиларном, педесетом Научном састанаку слависта у Вукове дане, који ће покушати да резимира србистичке и славистичке токове током последњих пола века и који ће се одржати у Београду током септембра 2020. године, многи пријављени реферати посвећени управо проучавању рускословенске и славеносрпске епохе. Готово читава једна секција тематски је груписана око „предвуковског” језика уз учешће већ афирмисаних домаћих и страних истраживача (Ана Кречмер из Беча, Александар Милановић из Београда, Исидора Бјелаковић из Новог Сада, али и младих истраживача (Александра Гајић из Беча).
} 
У њему су били српски лингвисти (Јован Јерковић, Велимир Михајловић, Јован Кашић, Светозар Стијовић, Љиљана Суботић), али и страни истраживачи (Александар Албијанић одн. Албин, Питер Херити, Јухани Нуорлуото). Сведочанство о овој делатности новосадске школе представља низ монографија о језику писаца и публициста из славеносрпске епохе, али и огроман број научних студија, расправа и радова. Истовремено, значајни центри истраживања славеносрпског језика постајали су и Београд, захваљујући пре свега истраживањима Ирене Грицкат и Михаила Стевановића, и Сарајево, у којем је деловала Херта Куна. Наравно, важне студије написали су и српски русисти (Богдан Терзић, Богдан Дабић). Крајем 20. и почетком 21. века формирао се и нови талас историчара српскога књижевног језика у Новом Саду (Исидора Бјелаковић, Милена Зорић), Београду (Александар Милановић, Ана Мацановић), Нишу (Ирена Цветковић Теофиловић) и Бањалуци (Биљана Бабић).

Независно од ових центара формирали су се истакнути истраживачи у иностранству, међу којима се морају издвојити имена слависта Никите И. Толстоја, Владимира П. Гуткова и Ане Кречмер. Веома корисне анализе и синтезе везане за „предвуковски период” нудили су и србисти првенствено синхронијског усмерења (Стана Ристић, Рајна Драгићевић) или истраживачи подједнако посвећени дијахронији и синхронији (Радоје Симић, Милош Ковачевић, Божо Ћорић). Наравно, не смеју се заборавити ни доприноси које су истраживању језика и језичких питања у „предвуковској епохи” дали историчари књижевности (Јован Скерлић, Драгиша Живковић, Милорад Павић), историчари уметности (Дејан Медаковић) или историчари друштва (Славко Гавриловић, Василије Крестић, Мирослав Јовановић).

2. Број истраживача славеносрпског језика и епохе, као и број њихових радова, с временом је, дакле, значајно растао, те се сада већ може говорити о богатој, стогодишњој традицији истраживања. Савремене студије и монографије, за разлику од пионирских, настају уз помоћ велике и разгранате литературе посвећене анализи различитих аспеката књижевнојезичке структуре (графија, ортографија, фонетика и фонологија, морфонологија, морфологија, творба речи, лексика, синтакса) или књижевнојезичке ситуације (диглосија, развој писмености, образовних система и штампарства, смена књижевнојезичких поставки и концепција, стилских формација итд.). Увид у постојећу литературу, међутим, неретко у први план доводи и огроман недостатак појединих савремених истраживања, у којима се често при анализама не консултује референтна литература. Узрок ове појаве је познат: радове о рускословенском, руском књижевном и славеносрпском језику објављује све већи број србиста у све већем броју различитих публикација, углавном у часописима и зборницима научних радова. У време несумњиве хиперпродукције радова у потрази за научним бодовима, нарочито радова у научним зборницима, проблем регистровања нових научних достигнућа буквално из месеца у месец постаје све израженији. Недаћу је могуће делимично решити или барем ублажити једино израдом библиографије радова и овај реферат ће се бавити теоријско-методолошким и оквирима такве публикације и практич- 
ним проблемима у њеној изради, те ће представљати завршетак разматрања о ресурсима за дијахронијска истраживања српског језика у 18. и 19. веку (Милановић 2017).

3. Празнина коју ствара непостојање библиографије радова о књижевним језицима „превуковске епохе” констатована је непосредно након формирања Одбора за стандардизацију српског језика у децембру 1997. године, већ на првим састанцима Комисије за историју језичког стандарда, коју су у почетку чинили: Бранислав Брборић, Славко Вукомановић, Милош Луковић, Александар Милановић, Александар Младеновић (председник), Милорад Пуповац, Светозар Стијовић, Божо Ћорић и Бранкица Чигоја (секретар). Председник Комисије Александар Младеновић, уз сагласност осталих чланова, одабрао је тим за израду библиографије радова, који су чинили Бранкица Чигоја и Александар Милановић, и дао основне теоријско-методолошке смернице за израду библиографије. Првобитна Младеновићева идеја била је израда интегралне библиографије радова из целокупне историје српског књижевног језика, од прихватања писмености до Вукове реформе. Такође, Младеновић је предлагао да критеријум за класификацију радова буде њихов извор, тј. да се радови групишу према часописима у којима су објављени (нпр. радови објављени у Јужнословенском филологу, потом Зборнику за филологију и лингвистику Матице српске, Српском језику и сл.). ${ }^{2}$ Процесом екцерпирања грађе из самих часописа и зборника, као и из литературе у постојећим монографијама, руководила је Бранкица Чигоја, која је формирала и свој тим, састављен од заинтересованих студената и постдипломаца. Задатак преписке са историчарима српског књижевног језика у циљу добијања њихових библиографија поверен је Александру Милановићу, аутору ових редова. ${ }^{3}$

4. Током израде библиографије радова из историје српског књижевног језика израњао је велики број тешко решивих теоријско-методолошких и практичних питања: да ли и како издвојити радове из историје народног језика посведоченог у споменицима (повеље, писма, уговори и сл.), какав статус у библиографији треба да имају текстолошке студије, какв статус дати језику у делима дубровачке књижевности (статус народног или књижевног језика), шта чинити са књижевноисторијским и историјским студијама у којима има значајних података о књижевном језику, и сл. Дискусије о овим питањима шириле су наша знања, али нису суштински допринела налажењу коначних

\footnotetext{
${ }^{2}$ Кључни недостатак ове концепције огледао се у чињеници да су радови истог аутора били расути на више места у библиографији, а да корисници библиографије углавном унапред не знају где је одређени рад објављен. Истовремено, оваква библиографија одређеним делом би се поклапала са објављеним библиографијама радова објављених у значајним часописима, чиме би губила на функционалности.

${ }^{3}$ У овом послу било је много непредвиђених тешкоћа. Како је почетком процеса интернет био још у повоју, преписка је добрим делом подразумевала слање класичних писама, неретко на застареле или погрешне адресе. Дешавало се и да аутори библиографије селектованих радова испишу руком, понекад нечитким рукописом, и сл. Није био ни мали број наведених погрешних података. Потпуно исти проблеми постојали су и током израде Биобиблиографског речника МСЦ 1971-2000 (Бојовић/Мршевић-Радовић/Самарџија 2005). Развој интернета ове техничке потешкоће смањује, али их не ништи.
} 
решења. Питања су остајала отворена. Процес израде интегралне библиографије прекинут је смрћу Александра Младеновића, а потом и смрћу Бранкице Чигоје. Оба одласка представљала су ненадокнадив губитак за рад Комисије, али и за читаву нашу научну дисциплину.

С временом, мењао се састав Комисије за историју језичког стандарда и ширио се број сарадника на процесу израде библиографије, а међу првима су се у процес укључили Виктор Савић и Ана Мацановић из Института за српски језик САНУ. Резултат нових састанака и консултација било је раздвајање процеса у изради библиографија. Није дискутабилно било да се библиографије морају односити на некадашњу делатност посленика културе на целокупном српском језичком простору. Израду библиографија за вишевековни период до прихватања рускословенског језика преузео је Виктор Савић, а за потоњи период Александар Милановић. Овде мислимо на епоху или период који се обично, па и у овоме раду по традицији, магловито именује као „предвуковски период". Он заправо подразумева време доминације рускословенског и славеносрпског језика, као и период конкуренције и коегзистенције норми, по терминолошким одређењима Никите И. Толстоја. Другим речима, период од прихватања рускословенског језика до победе вуковског језика у функцији књижевног тј. стандардног језика.

5. Израда библиографије радова о књижевним језицима „предвуковске епохе" отворила је бројна додатна теоријско-методолошка питања који се решавају током ексцерпције радова, од којих ћемо ради уштеде простора и фокусирања на кључне недоумице издвојити три најзначајнија. О њима смо, из уже перспективе и са другим циљем, већ писали, а поводом израде корпуса славеносрпских текстова и Речника славеносрпског језика Матице српске (Милановић 2017).

5.1. Прво је питање периодизација наведених епоха и временских граница између њих. Постојеће периодизације, а истаћи ћемо само Унбегаунову и Толстојеву, међусобно се разилазе, а приступ би ваљало уједначити. У наведеним периодизацијама, наиме, не поклапају се погледи на време прихватања руске редакције старословенског језика, а почетак славеносрпске епохе разликује се за две деценије: Никита И. Толстој (2004) га везује за 1760, а Борис Унбегаун (1995) за 1780. годину. Наспрам њих, већина српских историчара књижевног језика симболичким годинама прихватања рускословенског језика и настанка славеносрпског језика сматра године отварања прве руске школе у Сремским Карловцима (1726) и покретање Орфелиновог Славеносрпског магазина, првог часописа са прилозима на славеносрпском језику (1768). Обе постојеће периодизације показују и нужна методолошка ограничења јер је избор књижевног језика у тексту био предиспониран стилом и жанром више него преовлађујућом праксом у деценији у којој је стваран. Тако посвете или писма на славеносрпском језику пише чак и Вук Караџић, и то у време када друге текстове напоредо пише народним језиком.

5.2. Друго је питање одређења типа језика у већем броју текстова насталих у другој половини 18. и на почетку 19. века. Неретко се у литератури исти текст готово истовремено, а код различитих аутора, одређује или као 
текст писан српским народним или славеносрпским језиком, други као писан рускословенским или руским, и сл. Критеријуми за типолошка одређења до данас нису устаљени, а критеријум фреквенције одређених језичких (фонетско-фонолошких, морфонолошких, морфолошких) црта на основу познатог Младеновићевог упитника показао је и бројна ограничења, о чему је ауторитативно писала Ана Кречмер (1989). Укључивање пресудних фактора жанра текста и стила, које смо већ споменули, додатно спутавају домете оваквог приступа.

5.3. Треће питање у директној је вези и са првим и са другим, а односи се на крај славеносрпске и почетак вуковске епохе. И ово питање различито је решавано у референтној литератури, а постало је још компликованије после увођења појма и термина доситејевски језик, за шта су заслужна истраживања Павла Ивића. Иако неки истраживачи сматрају да је славеносрпски језик нестао током друге или треће деценије 19. века, ${ }^{4}$ на основу увида у тадашњу штампану продукцију у књижевности, науци, публицистици и администрацији лако се може констатовати његова несумњива коегзистенција са вуковским језиком барем до средине 19. века (1850).

6. Сви наведени теоријско-методолошки проблеми у вези са „предвуковском епохом” воде конкретном питању критеријума за класификацију библиографских референци. Чини се методолошки најпримеренијим да се при класификацији радова типолошки критеријум изостави (нпр. засебан одељак са списком радова о рускословенском, руском, славеносрпском књижевном језику и сл.). Ову идеју додатно оснажује чињеница да се и у оквирима истога текста насталог у „предвуковској епохи” могу наћи пасажи писани различитим стиловима, па и различитим књижевним језицима. Тешко је одредити где би, на пример, ваљало класификовати рад о Орфелиновом Славеносрпском магазину, као и о појединим другим Орфелиновим или Рајићевим делима. Доста добар пример укрштања различитих језичких израза нуде и Доситејеве басне.

Критеријум везан за анализирани ниво књижевнојезичке структуре (графија, ортографија, фонетика с фонологијом, морфонологија, морфологија, творба речи, лексика, синтакса) доноси нове проблеме јер је велики број радова у којима се не истражује само један ниво, почев од монографија о језику писаца па до студија и расправа. Навођење истог рада у више различитих одељака (нпр. истовремено и у одељку са радовима о графији и о фонетици, или и о морфологији и о синтакси) додатно би оптеретило библиографију и закомпликовало њену употребу.

Како два најрелевантнија критеријума у конкретном случају показују значајне функционалне недостатке, поставља се питање да ли би потрага за новим, додатним критеријумом деловала помало усиљено. Са друге стране, библиографија у којој би радови били само уазбучени према почетном слову презимена, поређани без икакве класификације, не би имала довољну упот-

\footnotetext{
${ }^{4}$ Најчешће се као гранична наводи 1818. година, односно година објављивања Српског рјечника Вука Стефановића Караџића. По овој поставци, после Вуковог лексикографског остварења доситејевског славеносрпског језика више нема у српској култури.
} 
ребну вредност. Проблем је, чини се, најједноставније решити навођењем кључних речи уз сваку библиографску референцу у штампаној верзији библиографије. ${ }^{5}$ Ваљало би их, према углавном устаљеној пракси, навести до 10. Уколико их аутор рада није сам навео, што је старија пракса, кључне речи мора одабрати аутор библиографије. На основу њих ће потом бити формиране класификације у електронској верзији библиографије, такође неопходној. Како електронска библиографија нема просторна ограничења, у њој би се могле наћи и друге сведене напомене њених аутора о наведеним радовима, на пример указивања на вредност, огрешења, одређене нужне паралеле и сл. Разлика у обиму штампане и електронске верзије библиографије била би, дакле, значајна.

7. Штампану верзију библиографије радова о језику „предвуковске епохе" ваљало би у почетку опрезно именовати као Грађа за библиографију радова о језику „,предвуковске епохе јер је тешко предвидети да у њој у првим издањима неће бити пропуста, изостављања појединих радова до којих је било тешко доћи (нарочито оних објављених давно, у иностранству и у мање познатим публикацијама). Како се оваква публикација периодично мора освежавати и допуњавати, њен наслов би требало с временом променити у Библиографија радова о језику „,предвуковске епохе” јер ће квалитетом, количином и тачноћу информација, заслужити преименовање. Електронска верзија библиографије мора у још већој мери бити процес него продукт, непрекидно отворена за нове допуне, прераде и коментаре, али број сарадника на њој мора бити добро одабран и ограничен.

Библиотечка обрада морала библиографских података требало би да почива на моделима устаљеним у Међународном славистичком центру у Београду (Библиографија 2016).

8. Непрекидни рад на ажурирању података на библиографији подразумеваће и даље претраживање и проверу података из различитих постојећих библиографија објављених радова, како појединих научника тако и часописа, анкетирање историчара српскога књижевног језика и, најзначајније, ексцерпирање података из нове продукције (монографија, радова из часописа и зборника). За сада временски оквир настанка регистрованих радова подразумева период од почетка 20. века до данас, али би границу у даљим истраживањима ваљало померати ка почетку 19. века и подацима из радова објављених у тадашњој периодици. У библиографију морају ући и подаци о одбрањеним а необјављеним магистарским радовима и докторским дисертацијама.

Напоредо са овом библиографијом, ваљало би радити и на библиографији радова о историји народног језика, у овој и претходним епохама. Заједно са библиографијама које већ публикује Виктор Савић, у којима су окупљена тумачења старословенског и српскословенског периода развоја српске писмености, ове библиографије чиниле би нераздвојну целину.

\footnotetext{
${ }^{5}$ И поред убрзаног развоја електронског издаваштва, штампану верзију библиографија и даље сматрамо научном неопходношћу у свакодневној пракси. О начелним разлозима за овакав став видети више у Каријер/Еко 2011.
} 
Коначан циљ стварања библиографије радова о језику „предвуковске епохе" јесте да он постане само један од сегмената будуће базе података о бурном и турбулентном развоју српског књижевног језика у оквирном периоду од 1740. до 1850. године. База би, поред библиографије, требало да садржи и корпус текстова, више различитих речника, скениране публиковане радове и монографије, и сл. За србистику је веома битно што су се у наведене процесе укључиле институције, Матица српска и Одбор за стандардизацију српског језика. Интересовање за истраживања првенствено славеносрпског језика, текстова и епохе непрекидно расте, а оваква база података и библиографија радова у њој несумњиво ће помоћи да број истраживача додатно порасте, али и да се отклоне недостаци данашње научне продукције те да се наша знања подигну на одговарајући ниво.

\section{ЛИТЕРАТУРА}

Библиографија 2012: Научни састанак слависта у Вукове дане 1-40 : библиографија 1971-2011 (прир. Злата Бојовић, Драгана Мршевић-Радовић и Катарина Тодоровић), Београд: Међународни славистички центар.

Библиографија 2016: Научни састанак слависта у Вукове дане : пројекти : библиографија : 2003-2016 (прир. Ивана Спасојевић), Београд: Међународни славистички центар.

Бојовић/Мршевић-Радовић/Самарџија 2005: Злата Бојовић, Драгана Мpшевић-Радовић и Снежана Самарџија, Биобиблиографски речник МСЦ : Научни састанак слависта у Вукове дане 1-30 : Учесници, Београд: Међународни славистички центар.

Каријер/Еко 2011: Žan-Klod Karijer i Umberto Eko, Ne nadajte se da ćete se rešiti knjiga, Čačak - Beograd: Gradac.

Ивић 1998: Павле Ивић, Преглед историје српског језика (прир. Александар Младеновић), Целокупна дела Павла Ивића, том VIII, Сремски Карловци - Нови Сад: Издавачка књижарница Зорана Стојановића.

Кречмер 1989: Anna Kretschmer, Zur Methodik der Untersuchung älterer slavischer schriftsprachlicher Texte (am Beispel des slavenoserbischen Schrifttums), München.

Милановић 2017: Александар Милановић, „Теоријско-методолошки проблеми стварања корпуса славеносрпских текстова", Научни састанак слависта у Вукове дане, 46/3, 2017, 137-145.

Толстој 2004: Никита И. Толстој, Студије и чланци из историје српског књижевног језика, Београд - Нови Сад: Завод за уџбенике и наставна средства - Вукова задужбина - Матица српска.

Унбегаун 1995: Борис Унбегаун, Почеци къижевног језика код Срба, Београд - Нови Сад: Вукова задужбина - Матица српска - Орфелин. 


\section{Aleksandar M. Milanović \\ BIBLIOGRAPHY OF REFERENCES ON THE LANGUAGE OF THE „PRE-VUKOVIAN PERIOD” AS A SOURCE FOR THE HISTORY OF STANDARD SERBIAN}

\section{Summary}

The paper gives a historical account of the process of compiling the list of written references on the language of the ,pre-Vukovian perod”. In addition, theoretical, methodological and practical obstacles that impede the compiling process are studied and explored. The author offers a structural outline and technical solutions for both electronic and „hard-copy” version of the biblography and provides guidelines for further revision and enlargment which are in turn highlighted as crucial for research in the field of the history of the literary standard of Serbian. 